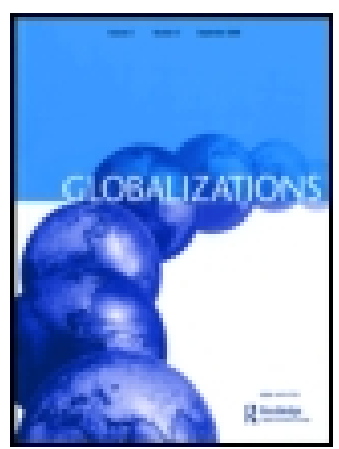

Globalizations

\title{
Great powers in global tax governance: a comparison of the US role in the CRS and BEPS
}

\section{Wouter Lips}

To cite this article: Wouter Lips (2018): Great powers in global tax governance: a comparison of the US role in the CRS and BEPS, Globalizations, DOI: 10.1080/14747731.2018.1496558

To link to this article: https://doi.org/10.1080/14747731.2018.1496558

册 Published online: 17 Jul 2018.

Submit your article to this journal $[\pi$

Џ Article views: 54

View Crossmark data \lceil 


\title{
Great powers in global tax governance: a comparison of the US role in the CRS and BEPS
}

\author{
Wouter Lips \\ Department of Political Science, Ghent University, Ghent, Belgium
}

\begin{abstract}
The G20 and the OECD recently claimed two successes in global tax governance: adopting automatic exchange of banking information in 2014, and the 2015 BEPS project on taxation of multinational companies. While the former signifies an essential step forward in reducing tax evasion, the BEPS outcomes were criticized for merely patching up flawed taxation principles based on the arms'-length standard. The emergence of global automatic exchange of information is often ascribed to the US who unilaterally enforced its own FATCA automatic information-exchange standard, while no comparable action happened during BEPS. This article investigates the US position on the BEPS outcomes and if a similar unilateral action would have led to more far-reaching cooperation concerning BEPS. By examining the distributional consequences of cooperation in both processes, we conclude that US power in tax governance in both issues is more limited than generally assumed and insufficient to explain global cooperation.
\end{abstract}

\section{KEYWORDS}

Tax governance; BEPS; automatic exchange of information; great powers; international taxation; tax cooperation

\section{Introduction}

Between 2008 and 2017, several sea-changes have occurred in international tax governance. Two key issue-areas in international taxation have been addressed by the group of 20 (G20) and the Organization for Economic Cooperation and Development (OECD). First, a review of practices regarding the international sharing of financial bank account data, which ended in the adoption of automatic exchange of information (AEoI) as a new global standard against tax evasion: the OECD's Common Reporting Standard (CRS). Second, the Base-Erosion and Profit-Shifting (BEPS) project that aims to ensure more adequate taxation of multinational companies (MNOs) by constraining their aggressive tax minimizing strategies.

The adoption of AEoI is widely seen as a fundamental improvement in multilateral tax cooperation. The BEPS Project, on the other hand has been criticized for not addressing the fundamental enablers of corporate tax avoidance: the transfer pricing regime and the arm's length standard (Büttner \& Thiemann, 2017).

This article will examine the role of the United States as a great power in international tax governance and how this impacted the diverging reach and effectiveness of these two initiatives. There is a general consensus amongst scholars that the exploitation of US market power was the breakthrough that led to AEoI becoming a new global norm (Eccleston \& Gray, 2014; Emmenegger, 2015b, 2015a; Grinberg, 2012; Hakelberg, 2015; Palan \& Wigan, 2014). In 2010 the Foreign Account 
Tax Cooperation Act (FATCA) was enacted in the United States, obliging foreign financial institutions to gather and share bank account information on US clients with the Internal Revenue Service (IRS). Because these foreign financial institutions (FFIs) faced a withholding tax of 30 percent on their US source income, the United States was able to ensure compliance by credibly threatening to effectively constrain their access to the US financial system on which they had become so dependent for their international operations. Hakelberg (2016a) therefore concludes that enforcement by a great power (e.g. FATCA) was crucial to facilitate global cooperation (e.g. the CRS) in tax governance, given that joint gains as a facilitator are almost impossible to realize in tax cooperation.

This article addresses two questions about the role of the US as a great power in tax governance. First, if successful reforms in information-exchange can be traced to US intervention, are the weak BEPS outcomes ascribable to US reticence? Second would a self-interested unilateral act by a great power, similar to FATCA, be sufficient to open a window for fundamental multilateral reform against BEPS practices?

Great power status in economic matters is derived from controlling a significantly large internal market and reduced vulnerability to external disruptions (Drezner, 2007). Concerning tax evasion, the only unambiguous great power is the US because of the structural power derived from the indispensable position of the dollar (Emmenegger, 2015b) for financial institutions. This grants the US the ability to impose its regulatory preferences on banks, who are the main suppliers of financial secrecy services (Hakelberg, 2016a).

In tax avoidance cooperation, the great power status of the US also holds. Using Hakelberg's (2016a, pp. 6-7) application of Drezner's aforementioned definition, Table 1 shows economic indicators in 2013 at the beginning of the BEPS process that show market size and vulnerability of the largest G20 economies. China, the US and the EU all control considerable consumer markets, yet China can cannot compare to the latter in terms of in- and outbound FDI. Losing access to the EU's or the US's market would thus be costlier for both capital exporting and importing countries than to China. China is also more dependent on international trade than the former, as shown by its trade to GDP ratio. According to Drezner's definition, the EU actually should hold more market power than the US. However, it is constrained by unanimity requirements and EU law. Small EU countries have a long history of blocking legislation for EU-wide anti-tax avoidance measures (Hakelberg, 2016a). The EU's market size thus does not necessarily translate into regulatory power on tax avoidance because of the mismatch between the scope of its market and the scope of its regulatory authority on tax matters (Newman \& Posner, 2011). Consequentially, the US also is the single great power in tax avoidance matters, although not quite as unambiguous as in tax evasion matters.

The implications of US preferences for international tax governance have been investigated by scholars in the past. Eccleston (2012, p. 134) remarks 'that since the 1960s the broad contours of

Table 1. Indicators of countries' economic power in 2013.

\begin{tabular}{lccccrr}
\hline Indicators & US & EU & CN & JP & RU & IN \\
\hline Population (Millions) & 316 & 507 & 1357 & 127 & 144 & 1252 \\
GDP (Current US\$, Billions) & 16800 & 17352 & 9240 & 4902 & 2097 & 1877 \\
Merchandise Trade (\%, global Imports) & 12.33 & 14.78 & 10.32 & 4.41 & 1.82 & 2.47 \\
Commercial Services (\%, global imports) & 9.85 & 19.74 & 7.52 & 3.70 & 2.81 & 2.84 \\
Trade to GDP ratio (2011-2013) & 30.1 & 34.9 & 51.9 & 33.6 & 51.5 & 54.2 \\
FDI (stock, outbound, \% world total) & 25.5 & 38.9 & 2.5 & 4.5 & 1.9 & 0.5 \\
FDI (stock, inbound, \% world total) & 19.4 & 33.7 & 3.8 & 0.7 & 2.3 & 0.9
\end{tabular}

Notes: Reproduced from Hakelberg (2016a). Based on WTO and UNCTAD data. 
international tax cooperation have been defined by changing US policy preferences'. Radaelli (1998) shows for example how changing US preferences led to revisions of transfer pricing guidelines in the OECD. Sharman (2006) describes how withdrawal of US support torpedoed the 1998 OECD Harmful tax competition project.

This article will argue that a FATCA-like event of a great power unilaterally defecting from the existing multilateral transfer pricing regime would not be sufficient to incite multilateral emulation of its preferred regulatory anti-avoidance standards. Compared to The CRS, the BEPS negotiations contained hard distributive conflicts over the increased revenue from cooperation. Unilateral defection by the US using coercive means to impose a self-interested allocation standard. would have revealed these distributive conflicts. G20/OECD members would not have multilaterally emulated the US' lead due to their interests being different from the US, which was not the case with AEoI. Instead, it is probable that the non-defecting negotiators would have adopted their own preferred standards in an uncoordinated unilateral fashion. This ultimately would lead to more source taxation for US resident MNOs, harming US interests.

The comparison introduces two additional explanatory variables next to the preferences of great powers: lack of redistributive conflict and alignment of interest among G20/OECD members. These were present while adopting AEoI and not during BEPS and have implications for the maneuvering room of a great power and the manner in which unilateralism can steer the outcome of a multilateral process. This does not mean that the US' preferences did not have impact on the BEPS process, as we will show how the US diluted the BEPS outcomes' effectiveness in an effort to defend its competitiveness interests. It does mean however that that US power in tax governance is more limited than would appear from FATCA.

This article's contributions are twofold. It is among the first to compare the two major initiatives of tax governance in recent years and furthers earlier political economy explanations of the BEPS process, such as Eccleston and Smith's (2016) exploration of G20 countries preferences and Grinberg's (2016) comparison with FATCA based on different law architectures. It also adds to a growing research on the role of the US in tax governance. Previous authors (e.g. Emmenegger 2015a; Hakelberg, 2015, 2016a) have focused on sources of power in tax governance or the necessity of great power action to overcome collective action problems. My argument shows that US powers in both the CRS and BEPS is more limited than what previous literature suggests. FATCA was a necessary step in forcing OFC's to share information, but is insufficient to explain why global emulation emerged. This is explained by the alignment of interest and lack of distributional conflicts in AEoI, which are inherent in BEPS. The BEPS case shows that the US is not able to impose its preferences unto other states and even reveals some weaknesses to anti-avoidance measures from other states targeting its MNOs, despite its great power status.

\section{CRS and BEPS: differences in reach and effectiveness}

Tax evasion is made possible by financial secrecy services that jurisdictions offer to foreigners, allowing them to avoid disclosing their wealth and earnings to their own governments. Such secrecy provisions can be found in a wide range of countries including EU- and OECD-members (Tax Justice Network, 2018). The international exchange of bank account information is one of the most effective remedies against such tax evasion. The OECD endorsed a standard based on information exchange on request since its 1998 harmful tax competition project (OECD, 1998; Sharman, 2006). However, this was an inadequate method for piercing the veil of banking secrecy, as tax administrations had to know in advance the name of the citizen suspected of tax evasion and all kinds of information 
(jurisdiction and financial institution where he/she held secret bank accounts) they were looking for in the first place (Grinberg, 2012). G20 members, growing dissatisfied with the on request standard, ultimately endorsed AEoI at the 2013 Saint-Petersburg summit (G20, 2013). AEoI obliges financial institutions to automatically share information on bank accounts held by foreign citizens. The G20 instructed the OECD with designing a multilateral coherent AEoI regime, culminating in the CRS (OECD, 2014), effectively ending banking secrecy among participants.

It proved more difficult to enforce a similar success in the other central issue area in international tax governance: tax avoidance by MNOs. MNOs artificially erode their tax base in high-tax countries and shift profits into low-tax jurisdiction by using tax planning techniques such as transfer pricing manipulation or thin capitalization (Genschel \& Schwarz, 2011; Palan \& Wigan, 2014). While none of these techniques are illegal per se, their (mis)use for tax-minimizing purposes is deemed problematic for a several reasons. First, MNOs' contribution to the fiscal resources of the state declined considerably over the past decades (OECD, 2015b), despite the fact they make persistent use of the public goods that are funded by tax resources. Second, local businesses do not have access to these techniques due to their domestic orientation, resulting in an unfair competitive disadvantage.

In order to alleviate these problems, the G20/OECD introduced the BEPS package with 15 action plans that aim to deal with specific dimensions of international tax avoidance strategies by MNOs. The overarching goal was the G20's statement that 'profits should be taxed where economic activities deriving the profits are performed and where value is created' (G20, 2013). BEPS is a soft law instrument. However, four minimum standards ${ }^{1}$ were agreed upon and these will be subjected to peer review.

Comparing BEPS to the CRS is not straightforward. When looking at the history of international tax reforms, BEPS is the biggest overhaul since the inception of the international tax regime. The agreement is certainly historic in that light (Deloite, 2015; PWC, 2014), especially considering the very short two-year timeframe. Compared to the CRS, BEPS covers a lot more ground. It will have great impact on the daily work of tax practitioners and will probably curb some egregious profit-shifting opportunities. But to be considered a success to the same degree as the CRS, BEPS would have to fundamentally solve the problem it tackles, and prove to be a robust consensus among countries. This is not the case, however. The reason is that BEPS does not change a fundamental design flaw of the international tax regime: the 'arm's length standard', which states that MNOs should value the intra-firm transactions between different subsidiaries as if they were being handled with a third independent party at market prices. The idea that subsidiaries of the same MNO located in different jurisdictions should be treated as separate legal entities for tax purposes is a legal fiction, in contrast with the economic reality that MNOs operate as integrated firms under centralized direction (Faccio et al., 2017).

Although the arms' length standard has been the cornerstone of the international taxation regime since the early twentieth century, many experts see it as one of the main enablers of profit-shifting especially for those transactions for which it is difficult to settle a comparable market value, such as intangibles and intellectual property rights (Baistrocchi, 2013; Cobham \& Jansky, 2015; Dharmapala, 2008; Kudrle, 2014; Palan, Murphy, \& Chavagneux, 2010; Rixen, 2010; Sharman, 2012; Zucman, 2015). Valuing the physical components of a smartphone is much easier than valuing the logo on the back, for instance. BEPS, however, is still based around this principle, and instead tries to close the loopholes that arise from the mismatch between the economic reality and legal fiction.

An alternative paradigm would be to view MNOs as a single legal entity for taxation purposes, in accordance to the economic reality of MNO's organized around global value chains. The best-known example is unitary taxation with formulary apportionment (UT + FA) where combined profits are 
allocated between states according to a pre-agreed weighing formula, usually based on sales, assets and labour. This approach of has been endorsed by numerous tax experts as a more viable way to stop MNO profit shifting (Avi-Yonah \& Tinhanga, 2017; Janský \& Prats, 2015; Picciotto, 2011; Rixen, 2010, 2011; van Apeldoorn, 2017). It is already in place within Canada and The US for allocating profits between provinces/states and is under consideration in the EU with the proposal of a Common Consolidated Corporate Tax Base (CCCTB). Another non-arms' length approaches is a destination-based cash flow tax. This proposes to apportion profits to the end location of sales, as consumers are the least mobile part of the value chain (Devereux \& De La Feria, 2014). It has been briefly considered by Republicans in the US with their border-adjustment tax proposal in 2016 (Chon, 2017).

This makes BEPS, from a political economy perspective, a missed opportunity. If the goal was to end double non-taxation (PWC, 2014), the arm's length solution appears insufficient. While the CRS is an effective step towards ending bank secrecy, BEPS leaves the fundamental enablers of profit shifting largely intact. Individual countries also demonstrate this as they felt the need to propose additional anti-avoidance measures outside of the BEPS recommendations such as the diverted profits tax in the UK, the EU CCCTB, or the base-erosion anti-abuse tax (BEAT) in the US. OECD tax director Saint-Amans dubbed the latter: 'a vote of none [sic] confidence for the arms' length principle' (Taxnote Talk podcasts, 2018, p. 17, 15). These developments cast doubt on both the effectivity in curbing profit shifting and political sustainability of the multilateral consensus based on the arms' length principle.

From a substance perspective, treating the adoption of a non-arms' length solution in one issue area and AEoI in another as comparable success benchmarks works as both mean significant progress towards solving their respective issues. Institutionally, however, there are technical differences that require explanation. AEoI was a new instrument layered onto the previously existing information-exchange upon request regime, and is not mutually exclusive with exchange-upon-request. Adopting AEoI requires the signing of a new OECD-based treaty called the 'Multilateral Competent Authority Agreement' which builds upon an article in the earlier widely-adopted 'Multilateral Convention on Mutual Administrative Assistance in Tax Matters' (OECD, 2016). As such, AEoI did not contravene the already existing regime, follows a logic of incremental change (Rixen, 2010) and adjustment costs were relatively low. Replacing the arm's length standard, on the other hand, requires the wholesale dismantling of the transfer pricing regime. This regime is regulated by a network of thousands of bilateral double tax treaties wherein states have large 'sunk costs' (Genschel \& Rixen, 2014). Adopting a non-arm's length system would require the renegotiation of all these treaties. It would also require an agreement on the formula to be used, to avoid mismatches. A process with significantly more adjustment costs.

BEPS did introduce an institutional innovation that could alleviate these costs: the BEPS multilateral instrument. This instrument allows states to amend all existing tax treaties with other signatory partners without having to renegotiate every one of them. It allows swifter implementation of $\mathrm{BEPS}$, as it also requires extensive changes to the treaty network, and the same logic could in theory also be used to introduce UT + FA. Avi-Yonah and Tinhanga (2017) argue that UT + FA could be indeed compatible with the existing treaty network. While still a major alteration of the tax governance regime, this would mean one of the fundamental building blocks of said regime could be conversed instead of dismantled in a less radical logic of change.

On the other hand, domestic adjustment costs of adopting AEoI should neither be understated. NGOs have pointed out that many developing countries for example do not have the capacity to implement AEoI. One could argue that states could pass on these costs unto banks, but this does 
not hold up for every G20 member. The BRICs banking system, for example, is largely state-owned (Nölke, Ten Brink, Claar, \& May, 2015) and these states could not defect these costs so easily.

The arms' length principle appears to be institutionally more resilient to change as the double tax treaties lock in and pacify distributive conflicts over tax allocation that states are not willing to address by opening these up (Rixen, 2010). In the section on BEPS, I will explain how these distributive conflicts limit the room for great power unilateralism.

\section{How FATCA led to the CRS}

The prevailing interpretation in the IPE literature on international tax governance is that the AEoI standard and its multilateral manifestation in the OECD's CRS regime ensued from unilateral actions by the United States and its unique structural power to ensure compliance. Although the European Union (EU) pioneered AEoI with the Savings Tax Directive in 2005, with extraterritorial effect as Switzerland and four other neighbouring countries participated, internal resistance from Austria, Luxemburg and Belgium prevented the Savings tax directive from being effective. These three countries were granted exceptions and could impose withholding taxes on foreign deposits instead of having to exchange information. The non-EU states then successfully demanded the same exception as these three countries (Hakelberg, 2015).

It was a 2010 US law that would serve as the catalyst for the multilateral shift to AEoI. The US government introduced FATCA in response to the UBS banking scandal, which revealed that many US citizens held secret Swiss bank accounts without reporting or paying the prevailing US taxes on these accounts. FATCA compels FFIs to gather information on the value - and income - of accounts held by US citizens or by foreign entities in which US citizens have a substantial interest or share, regardless of location, and report to the IRS beginning in 2014 (IRS, 2015). Remarkably, FATCA unilaterally demands compliance of FFIs over which the US holds no direct jurisdiction. In order to accomplish this, the US government imposes a penalty for non-compliance in the form of a $30 \%$ withholding tax on US-based financial activities, such as payments from US sources and proceeds from US investments, from non-complying FFIs (Grinberg, 2012; IRS, 2015).

The promotion of FATCA by the US government is widely seen as a 'game changer' that has helped the introduction of AEoI by ensuring the compliance of all the major offshore financial centres (OFCs) (Eccleston \& Gray, 2014; Emmenegger, 2015b). The centrality of the US dollarbased financial system in the world economy endowed the US government with the structural power to impose FATCA agreements onto OFCs. Emmenegger (2015b, p. 478) explains that due to the combination of international banks' economic dependence on access to the dollar-based financial system and the ability of US authorities to control access to it, even 'uncooperative' OFCs were forced to sign bilateral FATCA agreements with the United States and automatically share information on US residents' bank accounts with US tax authorities.

The capacity of the United States to impose AEoI onto OFCs was a key reason why the G20 instructed the OECD to design a multilateral framework, as the OECD itself admits (OECD, 2015a). In game theory terms, tax competition for portfolio investments through secrecy can be described as an asymmetrical prisoners' dilemma. Small states enjoy an advantage from noncooperation because domestic tax base losses are small compared to the amount of inward foreign investment they can attract by providing financial secrecy. Large states, as all G20 states are, cannot compensate the losses of their domestic revenues with inward portfolio flows. They face classic prisoner dilemma incentives, preferring collective agreement as they can expect an absolute increase of 
tax revenue, while small states prefer deadlock (Rixen, 2013). Small states thus will not cooperate unless they are forced to by large states through credible sanction threats (Hakelberg, 2016a).

FATCA imposed such credible sanction threats. This allowed other large states to essentially 'piggyback' on FATCA and realize cooperation amongst themselves. Meanwhile, for small secrecy jurisdictions, FATCA made it much harder for them to deny AEoI to other large states. This was especially prevalent in and around the EU. As Hakelberg (2015) convincingly argued, bilateral FATCA-agreements between the United States and EU member states allowed the EU to close the aforementioned exceptions in its 2005 Savings Tax Directive. The EU's 2011 Directive for Enhanced Cooperation contained a 'most favoured nation'-clause, which forced members to extend AEoI to all the other member states once they had granted it to the United States. FATCA stressed the need for a coherent intra-EU AEoI system, consolidating the EU's position regarding the desirability of a multilateral extension of the standard towards non-EU countries.

This unlocked the EU's potential as a great power in itself in tax governance, turning its eye towards Switzerland; whose cooperation in the Savings Tax Directive in 2005 proves the EU's ability to pressure it into tax compliance. FACTA-agreements led intra-EU-secrecy jurisdictions and EUfinancial institutions to become advocates of a globally uniform application of AEoI in order to level the playing field, avoid capital flight towards non-participants and minimize compliance costs associated with multiple standards (Eccleston \& Gray, 2014; Hakelberg, 2016a). This, in turn, put pressure on Switzerland who would also come to change preferences towards a uniform OECD standard. As such, FATCA provided a 'focal point' that other large countries could use 'to overcome collective action problems by coordinating their strategies and directing them against [non-complying OFCs]' (Emmenegger, 2015a, p. 3).

Besides being pressured by FATCA first and then the G20, the small island tax havens whose entire economy is built on financial services might also have had level-playing field interests in multilateral AEoI. Contrary to popular beliefs, research has shown that a vast majority of tax haven banks and financial institutions were more compliant with OECD transparency standards than financial institutions from the OECD countries (Findley, Nielson, \& Sharman, 2014, pp. 60-66), including their direct competitor Switzerland. The main reason is that these secrecy jurisdictions had more limited opportunities for undetected non-compliance, as they have been under much closer scrutiny since the 2000s. In this regard, participating in the CRS allowed these jurisdictions to level the playing field with the OECD countries due to its reciprocal nature, making sure that their banks and financial institutions would not be put at a competitive disadvantage (Interview with advisor of the IFC Forum, London, November 2016).

The question remains whether the unilateral action by the US to impose AEoI on non-complying states through its unique structural power in global finance was a sufficient condition for the G20/ OECD to embrace the new standard as a viable worldwide norm. As stated before large states can expect absolute tax revenue increases from cooperation in this area. Moreover, cooperation based on AEoI did not give rise to significant conflicts over the distribution of relative gains between the G20 members. As Grinberg (2016, p. 158) argues:

The combination of unilateral US coercive pressure and multilateral co-ordination towards a global standard for information-exchange succeeded because the underlying issue was an enforcement measure in which the interests among major economic powers were generally aligned and the benefits from agreement were non-rival.

The main reason is that two jurisdictions do not assert overlapping taxing rights over the same income of the same tax payer. Tax evasion through financial secrecy concerns passive forms of 
income, such as capital gains and interest payments, on assets that are hidden from the resident country government. The taxation rights on these types of income are allocated to the resident country by the OECD model treaty (OECD, 2014). Agreeing to automatically exchange information did not change these allocations.

The current CRS/FATCA-situation does have distributional consequences among large states but these are not the consequence of cooperation but rather of US defection. FATCA agreements, contrary to the CRS, are not necessarily reciprocal. Even the model agreement that provides the most reciprocity, is not nearly a quid pro quo (Christians, 2013). Furthermore, the Obama administration's proposals to fulfil their minor reciprocal obligations in the budgets of 2014-2017 were not approved by congress (US Office of Management and Budget, 2017). This situation allows the US to raise maximum revenue out of US citizens investments abroad, but by not reciprocating to essentially become one of the most attractive places to hide foreign capital as well, increasing the competitiveness of its domestic financial institutions. Especially when reciprocal AEoI became a global norm through the CRS. The US is aware of this and some domestic politicians champion this situation. This reveals the 'organized hypocrisy' where the US imposes its regulatory preferences on the global community without adhering to that standard itself. Hakelberg and Schaub (2017) show how FATCA redistributed foreign portfolio investments from tax havens to non-tax havens, but disproportionately to the US.

The persistence of FATCA next to the CRS can be explained by the sequence of events. It is conceivable that the G20/OECD would have ultimately reached an AEoI agreement with sanction threats without FATCA, but the order of events clearly show how FATCA set the CRS in motion. This locks in a strategic situation where the US is far better off non-cooperating and has no incentives to join the CRS but still allows other G20 governments to improve their own situation in terms of tax revenue by multilateral AEoI without room for redistributive conflict from cooperation.

\section{US preferences and redistributive conflicts in BEPS}

Multilateral cooperation against tax avoidance by MNOs is a different problem structure than cooperation against tax evasion, and this has strategic consequences for unilateral great power actions. The international tax rules for multinationals concern three intertwined problems: stopping profit shifting by MNOs, avoid double taxation, and determine the appropriate allocation of taxable profits between countries. The under-taxation of MNOs through harmful tax competition for paper profits is an asymmetric prisoner dilemma (Genschel \& Rixen, 2014; Radaelli, 1998), analogue to the information exchange, where a free-riding (small) state can improve its own position by providing profit shifting opportunities and/or preferential low tax rates even when the collective outcome is sub-optimal. However, avoiding double taxation and correctly allocating the tax base among countries is not a cooperation game, but a coordination game with distributional conflicts (Rixen, 2010). Countries have had a common preference to alleviate double taxation concerns since the 1930 s as they deem it detrimental for international business. As such they prefer a common standard. One country using a transfer pricing standard and another country applying UT + FA for example would almost definitely lead to double taxation. Different standards however can produce outcomes that allocate more or less tax base to different countries, as in a classic battle of the sexes problem (Radaelli, 1998). This means there are strong conflicts over the gains of cooperation among G20 states.

One such distributional conflict is the divergence of interests between countries that are net exporters of FDI and should favour stricter residence taxation rights and countries that are net 
receivers of FDI and should prefer stricter source taxation rights. As Figure 1 shows, there is a remarkable division within the G20 between those members - mostly OECD countries - that have accumulated a net stock of outward FDI and those - mainly emerging market economies with a net stock of inward FDI. The diverging interests between these two groups of countries made it much harder to reach an agreement on how to reform corporate taxation. Since the dominant OECD tax model treaties are generally regarded as more favourable towards residence countries (Cockfield, 2010), it is evident that the net source countries of the G20 tried to correct this imbalance through the BEPS process (Herzfield, 2016).

A second resident-source conflict occurred between the EU and the United States. While both are net residence countries in their own right, they are also each other's largest investor. This has resulted in an asymmetric bilateral FDI position that has made the United States a net residence country towards the EU and the EU a net source region towards the United States: in 201250.2 percent of US FDI stock abroad was located in the EU (Hakelberg, 2016b; UNCTAD, 2017), while only 31.8 percent of EU FDI stock was located in the US (Eurostat, n.d.). However, about 55 percent of US FDI stock in the EU is located in merely three countries. these are incidentally the top countries where US companies shift profits towards to reduce taxes: Luxemburg, Ireland and the Netherlands (Cobham \& Jansky, 2015; Hakelberg, 2016b; UNCTAD, 2017) ${ }^{2}$. Unanimity requirements prevented the EU Commission and the larger EU members from coercing these three smaller EU member states to give up their profit shifting attractiveness. The BEPS project gave these larger states and the Commission a forum to try and close some of these intra-EU deficiencies.

Radaelli (1998) asserts that the status quo in coordination games with distributional conflicts will be threatened by large states trying to force other actors into different equilibrium outcomes, rather

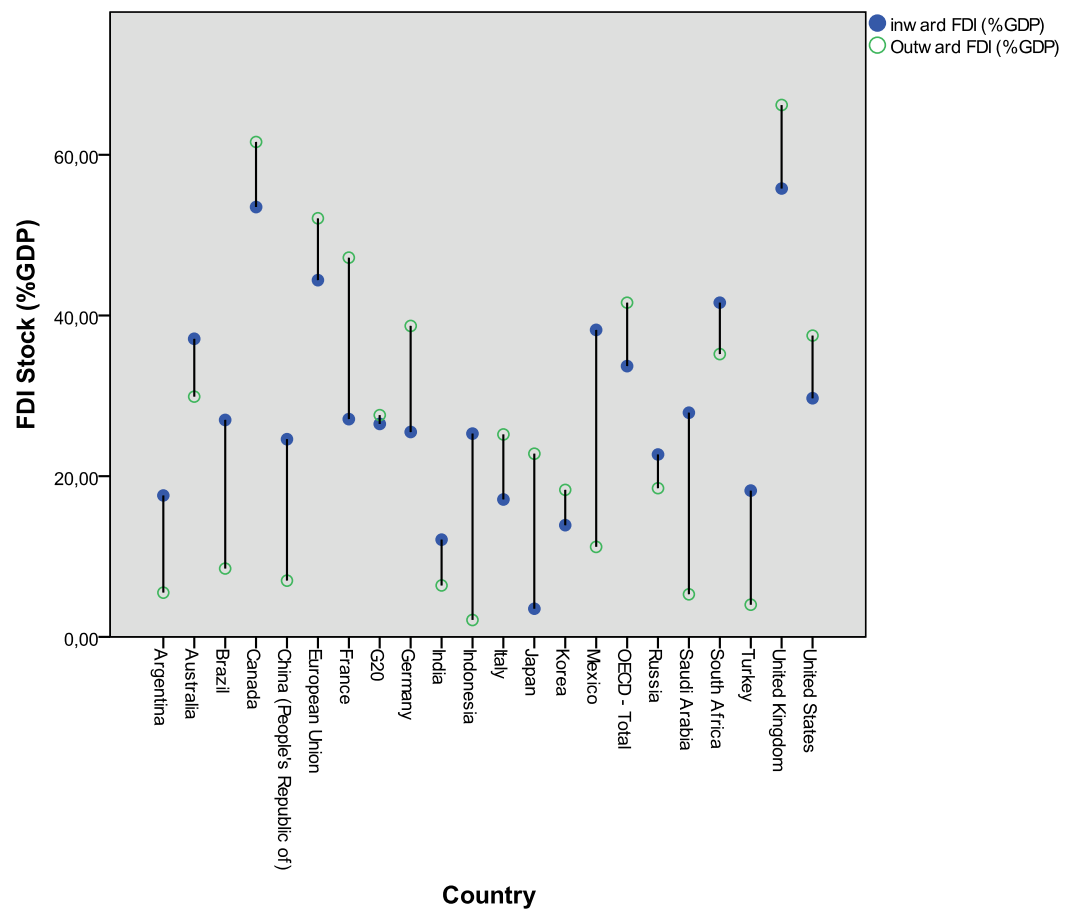

Figure 1. Comparison of G20 inward and outward FDI stock, 2012. Source: (OECD, 2015c). 
than small states freeriding. He shows how US intervention led to a revision of the OECD transfer pricing guidelines in 1995, driven by a desire to halt Japanese and European companies minimizing their taxable presence in the US. This revision introduced profit-split methods, which can be described as a formulary approach to transfer pricing. Another past example of how US' preferences shaped international tax governance is its pioneering of Controlled Foreign Company (CFC) rules in the 1960s to prevent US multinationals stripping profits out of the US. The broad aim of CFC legislation is to treat wholly owned subsidiaries of companies that are located in OFCs, yet are involved in little if any real economic activity, as if they were located in the same jurisdiction as the parent company (Eccleston, 2012, p. 21). As such, CFC rules are both residence country-strengthening and a digression from the separate entity principle. CFC-rules diffused throughout the OECD throughout the following decade. These past examples show that the US can use its market power to change the arms-length status quo to more favourable outcomes, even if this goes against the interests of other countries or leads to more domestic taxation of US citizens (Eccleston, 2012; Hakelberg, 2016a). This also implies US preferences would have critical impact on the final BEPS outcomes.

In order to understand the position and interests of the United States during the BEPS negotiations, it is important to first clarify several idiosyncrasies of the US tax system at the times of BEPS. First, it was based on a world-wide taxation system instead of the more common territorial system. US tax authorities treat the entire tax base of companies that operate in the United States as theirs to tax and do not exempt taxation rights on active income earned abroad in source countries, instead providing a credit to US companies against taxes paid in a foreign country (Cadesky \& Lobo, 2014). Second, the 'deferral option' allows US companies to indefinitely postpone the payment of taxes on their foreign profits as long as these profits are not repatriated ${ }^{3}$. This is essentially a subsidy on US MNOs foreign activities and increases their competitiveness as they can reinvest foreign profits without paying taxes on them (Grinberg \& Pauweleyn, 2015). The deferral option gives US MNOs an additional incentive to engage in foreign-to-foreign tax planning, shifting profits through several subsidiaries in different jurisdictions in order to lower taxes paid outside the US (Grinberg \& Pauweleyn, 2015). The US government had a keen interest in preserving their ability to do so during BEPS: the less taxes US MNOs pay outside the US, the smaller the credit the US government has to provide and the more tax revenue goes into the US treasury at the moment of repatriation. Even if companies do not repatriate, they retain a competitive edge over non-US competitors.

This predicts US preferences in the BEPS negotiations. It should want to halt US MNOs from avoiding US taxes, but at the same time retain their abilities to engage in cross-border tax planning abroad and avoid foreign taxes by exploiting the arms' length standard. Accordingly, the United States entered the BEPS negotiations stressing the importance of stricter CFC rules to mitigate BEPS practices (Grinberg, 2015). This coincides with past examples where the US challenged agreed rules to protect its own tax base, but never bothered with realigning US MNOs activities and tax liability abroad. This also means it has limited interest in truly achieving international taxation where economic activity takes place. Cobham and Jansky (2015) show the redistributive consequences of applying unitary taxation for US MNOs. It would allocate 463 billion US Dollars in missing taxable profits to the US. However, the US misses out on that profit partly by own choice due to the deferral option. It would also redistribute foreign profits from low tax jurisdictions such as the Netherlands and Ireland to higher tax jurisdictions such as Germany and Brazil leading to a higher tax burden for US MNOs abroad and larger tax credits in the US. This assessment is not only valid for unitary taxation, any reform towards the goal of aligning economic value creation and taxation would necessarily result in less foreign-to-foreign tax planning opportunities for US MNOs. 
Nevertheless, BEPS package however includes provisions that strengthen source taxation against US interests, such as preventing profit stripping through interest deduction limitations, or lowering the permanent establishment threshold. If the US holds such influence over the outcome of tax governance, why did they accept this? The main problem for the United States was that unilateral withdrawal from the BEPS initiative would not necessarily have compelled the other G20 and OECD countries to discontinue tax reform efforts, resulting in even more and stricter source countrystrengthening stipulations. Because of US MNO's reliance on foreign-to-foreign tax planning, what foreign parliaments do and how they tax cross-border income between foreign subsidiaries is as important as what the US does (Grinberg \& Pauweleyn, 2015). The US was aware of this risk, as evidenced by a testimony by the deputy assistant treasury secretary for international taxation and chief BEPS negotiator before the Ways and Means committee in 2015:

Failure in the BEPS project could well result in countries taking unilateral, inconsistent actions, thereby increasing double taxation, the cost to the US Treasury of granting foreign tax credits, and the number and scale of tax disputes. (Stack, 2015)

In this regard, of utmost importance were the outcomes on the digital economy. As the same deputy assistant secretary commented on record,

the United States is one of the few countries that seems to have a vibrant digital economy, consequently, the BEPS work in that area had more of a flavor of people seeking to increase their revenue regardless of the principles that might be applied.

Moreover, he argued that 'countries participating in the OECD/G20 BEPS project sought to rewrite international tax rules for the digital economy and for intellectual property to increase their tax take at the expense of the United States' (Stack, quoted in Martin, 2016).

This challenge to US interests was (and still is) most visible in the EU. There, the EU Commission used its authority on competition to investigate certain tax rulings or 'sweetheart deals' extended by member states to MNOs by framing these as unfair state support and forcing those member states to reclaim due taxes or face monetary sanctions. Large US technology MNOs were among the main beneficiaries of these rulings, and US politicians felt these were unrightfully envisaged by the EU commission calling the EU tax climate 'hostile' (Jopson \& Oliver, 2016). As the Obama treasury administration argued in a white paper with bipartisan support,

these investigations, if continued, have considerable implications for the United States for the US government directly and for US companies in the form of potential lost tax revenue and increased barriers to cross-border investment. (US Department of the Treasury, 2016)

This shows that if the EU leverages its own market power, even against some member states' wishes, its regulatory acts can have far-reaching consequences to US interests. It also explains why the US would agree to multilateral BEPS outcomes containing provisions that at face value run against its revenue or competitiveness interests. It serves as a check on unilateral source-country measures, which were potentially more harmful than a weakened BEPS outcome, and to protect what it saw as its vital interests in some issue areas like the digital economy. Notably, using multilateralism in taxation to prevent unilateral actions by source countries is not a new strategy for the United States. Historical tax accounts describe this as the rationale for the US to step into bilateral treaty networks in the 1930s (Graetz \& O'Hear, 1997; Picciotto, 1989). The same line of thinking was applied by US officials to the BEPS process. The US diluted some BEPS proposals, such as the work on hybrids, or 
digital economy ${ }^{4}$ (The Economist, 2015) and later backed out of some parts such as the Multilateral Instrument.

In sum, The BEPS outcomes are in part a function of US reticence. It also shows that the US ability to impose its own preferences unto others was hampered by redistributive conflicts of cooperation with other large states, exacerbated by the inclusion of non-OECD G20 states in the negotiations, its own unwillingness to defect unilaterally and the EU's potential counterweight as great power in this field. If the US, in a FATCA-like exercise of market power, would have tried to unilaterally impose a non-arms' length approach to allocating profits on third countries according to a formula that served US interests, it would not have led to multilateral emulation of that US enforced standard. Instead, it would have fully opened up the source-resident conflicts already tangible in the BEPS work on digital economy. Others would attempt to curb US MNOs profit shifting from source countries either unilaterally or with regional coordination, for example in the EU with formulae that reflected their own interests. The would imply both tax revenue losses for the US and a loss of competitiveness for US MNOs. While past examples of tax reform show that the US has sufficient market power to avoid foreign companies from eroding the domestic US tax base, it does not possess the power to avoid other jurisdictions doing the same to US MNOs, especially when these are important markets for US MNOs.

\section{Conclusion}

As this article's analysis of the role of the United States as a great power in the emergence of the OECD's CRS regime and BEPS package has shown, the relative success of adopting AEoI and abolishing banking secrecy; and failure of abandoning the arms'-length approach cannot be merely explained by the unilateral action by the United States in the first initiative and the absence thereof in the latter.

With respect to AEoI, the alignment of interests among G20 states and lack of distributive conflict enabled unilateral defection by the United States in the form of FATCA to result in a multilateral emulation with the CRS. Even though FATCA/CRS coexistence locks in a situation that disproportionately attracts foreign portfolio flows to the US, multilateral AEoI still allowed large states to improve their own position in terms of absolute tax revenue and from a global point of view also advance collective tax fairness goals.

The FATCA coercive redistribution model does not seem applicable to cooperation against tax avoidance. The redistributive source/residence-conflicts of coordination between large states that are inherent in this issue area mean that even a great power cannot replicate what the US did in FATCA: unilaterally coerce other states to help protect its tax base, without its competitiveness or revenue interest harmed by the reaction of other states. A unilateral defection from the OECD standards, even if the US on its own could then prevent its tax base from being eroded, would not lead to emulation but to other large states introducing their own measures that would lead to US MNOs being subjected to more source taxation. This would harm both US competitiveness and tax revenue interests.

This does not mean that great power preferences do not matter in this field. My analysis shows US reticence had impact on the BEPS outcomes, and that a strategy of diluting BEPS from within is in line with a long-standing strategy of using multilateral frameworks to limit source countries' taxation capacities. What this shows is that the strategic nature of the different issue areas limit how a great power can wield its capacity to protect its interests against other states in tax governance problems: 
unilateral enforcement or multilateral impedance. A FATCA-like event in tax avoidance cooperation would thus be insufficient to realize a global non-arms' length standard.

However, there might be causes for cautious optimism: On the one hand, as the non-OECD states in the G20 continue to rise economically, they could also become net resident countries like most OECD countries, alleviating the division of interests within the G20. On the other, if the EU could manifest itself as a great power in international taxation, growing tensions with the US and consequential uncertainty for businesses might lead to US MNOs themselves supporting a more certain standard such as unitary taxation over the tax planning opportunities of the arms'-length standard. Much more than a FATCA-like event, these two developments might offer a chance in the future to truly tackle corporate taxation at the G20 level.

\section{Notes}

1. Countering harmful tax practices, country-by-country reporting, avoiding treaty abuse and effective dispute resolution.

2. This makes some large EU countries, such as Germany and France and the UK, net residence countries towards the US. Their largest intra-EU investor countries are the Netherlands and Luxembourg however (UNCTAD, 2017). These countries serve as gateways for US investments into the common market. Germany, France and the UK are also among the top 10 jurisdictions missing profits from US MNOs (Cobham \& Jansky, 2015). They are thus on the source side of the conflict.

3. The 2017 Tax Cuts and Jobs Act moves towards a more territorial system without deferral. Although the effects of this reform are not yet clear, one interpretation is that the TCJA is an attempt to incentivize US MNO's to relocate foreign capital back to the US.

4. All substantial work was passed to a subsidiary of the OECD Committee on Fiscal Affairs (the Task Force on Digital Economy) whose final report and recommendations on digital economy are not expected before 2019 .

\section{Acknowledgements}

I would like to thank Mattias Vermeiren, Dries Lesage, Rasmus Christensen and the participants of my panel at ISA 2017, along with two anonymous reviewers and the editors for their insightful and valuable comments on earlier drafts of this article. All remaining mistakes remain entirely my own.

\section{Disclosure statement}

No potential conflict of interest was reported by the author.

\section{Funding}

This work was supported by the Research Foundation - Flanders.

\section{Notes on contributor}

Wouter Lips is a PhD researcher at Ghent University, funded by the Research Foundation - Flanders. His work focusses on global tax governance.

\section{ORCID}

Wouter Lips (D) http://orcid.org/0000-0003-3801-8727 


\section{References}

Avi-Yonah, R., \& Tinhanga, Z. P. (2017). Formulary apportionment and international tax rules. In S. Picciotto (Ed.), Taxing multinational enterprises as unitary firms (pp. 67-75). Brighton: ICTD.

Baistrocchi, E. A. (2013). The international tax regime and the BRIC world: Elements for a theory. Oxford Journal of Legal Studies, 33(4), 733-766.

Büttner, T., \& Thiemann, M. (2017). Breaking regime stability? The politicization of expertise in the OECD/ G20 process on BEPS and the potential transformation of international taxation. Accounting, Economics, and Law: A Convivium, 7(1), 449.

Cadesky, M., \& Lobo, K. (2014). The US view on BEPS. In AOTCA 2014.

Chon, G. (2017). Breakdown: Border tariff vs. border-adjustment tax. Retrieved from https://www.reuters.com/ article/us-usa-trump-breakingviews/breakdown-border-tariff-vs-border-adjustment-tax-idUSKBN15920G

Christians, A. (2013, April). What you give and what you get: Reciprocity under a model 1 intergovernmental agreement on FATCA. Cayman Financial Review. Retrieved from http://www.caymanfinancialreview.com/ 2013/04/12/what-you-give-and-what-you-get/

Cobham, A., \& Jansky, P. (2015). Measuring misalignment: The location of US multinationals' economic activity versus the location of their profits (ICDT Working Papers, 42).

Cockfield, A. (2010). Globalization and its tax discontents. Toronto: University of Toronto Pres.

Deloite. (2015). Fiscal revolution BEPS: Companies must get ready for major changes to international tax rules. Retrieved from https://www2.deloitte.com/ro/en/pages/tax/articles/fiscal-revolution-beps.html

Devereux, M., \& De La Feria, R. (2014, May). Designing and implementing a destination-based corporate tax (Working Papers 14/07). Oxford University Centre for Business Taxation.

Dharmapala, D. (2008). What problems and opportunities are created by tax havens? Oxford Review of Economic Policy, 24(4), 661-679.

Drezner, D. (2007). All politics is global. Explaining international regulatory regimes. Princeton: Princeton University Press.

Eccleston, R. (2012). The dynamics of global economic governance. The financial crisis, the OECD and the politics of international tax cooperation. Cheltenham: Edward Elgar Publishing.

Eccleston, R., \& Gray, F. (2014). Foreign accounts tax compliance act and American leadership in the campaign against international tax evasion: Revolution or false dawn? Global Policy, 5(3), 321-333.

Eccleston, R., \& Smith, H. (2016). The G20, BEPS and the future of international tax governance. In P. Dietsch \& T. Rixen (Eds.), Global tax goverance: What is wrong and how to fix it (pp. 175-199). Colchester: ECPR Press.

The Economist. (2015). New rules, same old paradigm. Retrieved from https://www.economist.com/news/ business/21672207-plan-curb-multinationals-tax-avoidance-opportunity-missed-new-rules-same-old

Emmenegger, P. (2015a). Swiss banking secrecy and the problem of international cooperation in tax matters: A nut too hard to crack? Regulation and Governance, 11(1), 24-40.

Emmenegger, P. (2015b). The long arm of justice: U.S. structural power and international banking. Business and Politics, 17(3), 473-493.

Eurostat. (n.d.). Top 10 countries as extra EU-28 partners for FDI positions, EU-28, end 2012-14 (billion EUR). Retrieved from http://ec.europa.eu/eurostat/statistics-explained/index.php/File:Top_10_countries_as_extra_ EU-28_partners_for_FDI_positions,_EU-28,_end_2012\%25E2\%2580\%259314_(billion_EUR)_YB16.png

Faccio, T., Picciotto, S., Brockmeyer, A., Clausing, K., Durst, M., Fleming, C., \& Nerudová, D. (2017). Alternatives to the separate entity / arm's length principle. ICRIT.

Findley, M. G., Nielson, D. L., \& Sharman, J. C. (2014). Global shell games. Experiments in transnational relations, crim, and terrorism. Cambridge: Cambridge University Press.

G20. (2013). G20 Saint-Petersburg summit leader's declaration.

Genschel, P., \& Rixen, T. (2014). Settling and unsettling the transnational legal order of international taxation, 1-24. Retrieved from http://www.eui.eu/Documents/DepartmentsCentres/SPS/Profiles/Genschel/ SPSGenschelRixen2014.pdf

Genschel, P., \& Schwarz, P. (2011). Tax competition: A literature review. Socio-Economic Review, 9(2), 339370.

Graetz, M., \& O’Hear, M. (1997). The “original intent” of US international taxation. Duke Law Journal, 46, 1021-1109. 
Grinberg, I. (2012). Beyond FATCA: An evolutionary moment for the international tax system (working draft). SSRN Electronic Journal. Retrieved from https://ssrn.com/abstract $=1996752$

Grinberg, I. (2015). Breaking BEPS: The new international tax diplomacy. SRRN Electronic Journal. Retrieved from https://ssrn.com/abstract=2652894

Grinberg, I. (2016). Does FATCA teach broader lessons about international tax multilateralism? In P. Dietsch, \& T. Rixen (Eds.), Global tax goverance: What is wrong and how to fix it (pp. 157-175). Colchester: ECPR Press.

Grinberg, I., \& Pauweleyn, J. (2015). The emergence of a new international tax regime: The OECD's package on base erosion and profit shifting (BEPS). ASIL Insights, 19(24), Retrieved from https://www.asil.org/insights/ volume/19/issue/24/emergence-new-international-tax-regime-oecd\%25E2\%2580\%2599s-package-baseerosion-and

Hakelberg, L. (2015). The power politics of international tax co-operation: Luxembourg, Austria and the automatic exchange of information. Journal of European Public Policy, 22(3), 409-428.

Hakelberg, L. (2016a). Coercion in international tax cooperation: Identifying the prerequisites for sanction threats by a great power. Review of International Political Economy, 2290, 1-31.

Hakelberg, L. (2016b). Power in international tax policy. The preconditions and redistributive consequences of credible sanction threats. Florence: European University Institute.

Hakelberg, L., \& Schaub, M. (2017, March). The redistributive impact of hypocrisy in international taxation. Regulation \& Governance. doi:10.1111/rego.12156

Herzfield, M. (2016, December 12). India and the United States - half a world apart on tax. Tax Notes.

IRS. (2015). Foreign account tax compliance act. Retrieved from https://www.irs.gov/Businesses/Corporations/ Foreign-Account-Tax-Compliance-Act-FATCA

Janský, P., \& Prats, A. (2015). International profit-shifting out of developing countries and the role of tax havens. Development Policy Review, 33(3), 271-292.

Jopson, B., \& Oliver, C. (2016). US lawmakers slam 'hostile' EU tax climate. Financial Times. Retrieved from https://next.ft.com/content/a40e4b34-c9c7-11e5-be0b-b7ece4e953a0

Kudrle, R. T. (2014). The OECD and the international tax regime: Persistence pays off. Journal of Comparative Policy Analysis: Research and Practice, 16(3), 201-215.

Martin, J. (2016). Countries targeted US companies in BEPS project to increase tax revenue, US treasury official charges. Retrieved from http://mnetax.com/countries-targeted-us-companies-beps-increase-tax-revenuetreasury-stack-15131-15131

Newman, A. L., \& Posner, E. (2011). International interdependence and regulatory power: Authority, mobility, and markets. European Journal of International Relations, 17(4), 589-610.

Nölke, A., Ten Brink, T., Claar, S., \& May, C. (2015). Domestic structures, foreign economic policies and global economic order: Implications from the rise of large emerging economies. European Journal of International Relations, 21(3), 538-567.

OECD. (1998). Harmful tax competition: An emerging global issue, 1-82.

OECD. (2014). Standard for automatic exchange of financial account information in tax matters, 311.

OECD. (2015a). Common reporting standard. Retrieved from http://www.oecd.org/tax/automatic-exchange/ common-reporting-standard/

OECD. (2015b). Corporate tax revenues falling, putting higher burdens on individuals. Retrieved from http:// www.oecd.org/newsroom/corporatetaxrevenuesfallingputtinghigherburdensonindividuals.htm

OECD. (2015c). FDI DATA. Retrieved from https://data.oecd.org/fdi/fdi-flows.htm

OECD. (2016). The CRS multilateral competent authority agreement. Retrieved from http://www.oecd.org/tax/ automatic-exchange/international-framework-for-the-crs/

Palan, R., Murphy, R., \& Chavagneux, C. (2010). Tax havens. How globalization really works. Ithaca: Cornell University Press. doi:10.1017/CBO9781107415324.004

Palan, R., \& Wigan, D. (2014). Herding cats and taming tax havens: The US strategy of 'not in my backyard'. Global Policy, 5(3), 334-343.

Picciotto, S. (1989). Slicing a shadow. In L. Hancher \& M. Moran (Eds.), Capitalism, culture, and economic regulation (pp. 11-48). Oxford: Oxford University Press.

Picciotto, S. (2011). Regulating global corporate capitalism. Cambridge: Cambridge University Press.

PWC. (2014). An interview with Pascal Saint-Amans. Retrieved from https://www.pwc.com/gx/en/tax/taxpolicy-administration/beps/assets/pwc-tax-interview-transcript.pdf 
Radaelli, C. M. (1998). Game theory and institutional entrepreneurship: Transfer pricing and the search for coordination international tax policy. Policy Studies Journal, 26(4), 603-619.

Rixen, T. (2010, April). From double tax avoidance to tax competition: Explaining the institutional trajectory of international tax governance. Review of International Political Economy. http://doi.org/10.2139/ssrn. 1589132

Rixen, T. (2011). Tax competition and inequality: The case for global tax governance. Global Governance, 17 (4), 447-467. Retrieved from http://doi.org/http://www.heinonline.org/HOL/Page?handle=hein.journals/ glogo17\&id $=455 \&$ collection $=$ journals\&index $=$ journals/glogo

Rixen, T. (2013). Why reregulation after the crisis is feeble: Shadow banking, offshore financial centers, and jurisdictional competition. Regulation \& Governance, 7, 435-459.

Sharman, J. C. (2006). Havens in a storm. The struggle for global tax regulation. Ithaca: Cornell University Press. Sharman, J. C. (2012). Seeing like the OECD on tax. New Political Economy, 17, 17-33.

Stack, R. B. (2015). Testimony of Robert B. Stack, deputy assistant secretary (international tax affairs) U.S. department of the treasury before the ways and means subcommittee on tax policy December 1, 2015 chairman.

Tax Justice Network. (2018). Financial secrecy index - 2018 results. Retrieved from http://datafortaxjustice.net/ paradiselost/

Taxnote Talk podcasts. (2018). Tax challenges of the digital economy. Retrieved from https://www.taxnotes. com/tax-notes-talk

UNCTAD. (2017). Bilateral FDI data. doi:10.1111/j.1475-6765.2007.00760.x

US Department of the Treasury. (2016). The European Commission's recent state aid investigations of transfer pricing rulings (White Paper).

US Office of Management and Budget (2017). Fiscal year 2017. Analytical perspectives. Budget of the US governement. Retrieved from https://www.gpo.gov/fdsys/pkg/BUDGET-2017-PER/pdf/BUDGET-2017PER.pdf

van Apeldoorn, L. (2017). BEPS, tax sovereignty and global justice. Critical Review of International Social and Political Philosophy, 15, 1-22.

Zucman, G. (2015). The hidden wealth of nations. The scourge of tax havens. Chicago: The University of Chicago Press. 